\title{
DOS FILHOS ORIUNDOS DE INSEMINAÇÃO ARTIFICIAL
}

Luan Christ Rodrigues Roseli Christ

ISSUE DOI: $10.21207 / 1983.4225 .285$

\section{RESUMO}

A pós-modernidade trouxe consigo a intensificação antropogenética dos avanços da tecnociência médica; tal constatação localiza-se, entre outros aspectos, na colisão de valores que circundam a procriação humana assistida, mais especificamente, na análise do embate entre o direito ao anonimato do doador de gametas e o direito à identidade do concebido advindo da inseminação artificial. Busca-se, assim, mensurar os valores atratores envoltos em ambos os Direitos, atendo-se aos princípios constitucionais, com espeque na interpretação axiológica tópico-sistemática, arrimada pela legislação e doutrina pátria, além de nuances do Direito Comparado, resguardando o bem jurídico que possua carga axiológica que perfectibilize o enfraquecimento do outro no caso concreto.

Palavras-chave: Reprodução humana assistida. Sigilo do doador. Identidade pessoal. Transdisciplinaridade.

\section{INTRODUÇÃO}


O presente trabalho pugna desmembrar, por um lado, o direito ao sigilo de identidade do doador de gameta, permitindo mensurar sua carga axiológica, isto é, os valores que o alicerçam, tomando como ponto de partida o direito à vida privada e à intimidade, e por outro, o direito à identidade pessoal, com amparo no direito à personalidade, ambos insculpidos na Constituição Federal.

Assim, serão abordados argumentos distribuídos em três capítulos, que ensejarão no desvelar do núcleo da problemática, com base nos princípios constitucionais na promoção do Estado Social e Democrático de Direito.

No primeiro capítulo, apresentar-se-á uma abordagem quanto à carga axiológica do direito ao sigilo de identidade do doador, especialmente pelo debate doutrinário, jurisprudencial e por intermédio, arrazoado, inclusive, pela importância do amparo à solidez do grupo familiar do concebido.

No segundo capítulo, tomando por base a fundamentação vergastada no primeiro, serão realizados apontamentos sobre os direitos da personalidade, bem como uma breve abordagem sobre a importância da autonomia privada, da identidade e da historicidade pessoal atrelada ao inconsciente do ser.

Na sequencia, trabalhar-se-á a colisão dos direitos fundamentais em análise, na incidência tópico-sistemática, com escopo nas legislações internacionais, demonstrando-se, assim, a posição defendida frente à problematização esboçada, sob a exegese transdisciplinar.

\section{DIREITO AO SIGILO DE IDENTIDADE DO DOADOR DE MATERIAL GENÉTICO}

Para melhor análise dos limites ético-jurídicos da reprodução assistida heteróloga, imperioso delimitar questões atinentes à condição do vínculo sócio-afetivo, conforme o regramento do Direito de Família, amparado pelo Código Civil. ${ }^{1}$

\footnotetext{
${ }^{1}$ BRAUNER, Maria Claudia Crespo. Reprodução Humana Assistida e Anonimato de doadores de Gametas: $O$ Direito brasileiro frente às novas formas de paternidade. In: Tereza Rodrigues Vieira (Org.). Ensaios de Bioética e Direito. 2 ed. rev. ampl. atual. Brasíla DF: Consulex, 2012. p. 39.
} 
Quando é realizada uma adoção, por exemplo, o Direito Pátrio contempla a filiação em sua totalidade, cessando todo e qualquer vínculo com a família consanguínea, com o consequente sigilo de informações dos pais biológicos garantido pelo cartório de registro civil das pessoas físicas. ${ }^{2}$

Com o avanço de pesquisas científicas, os indivíduos adotados, seja por aspectos psíquicos, morais ou pela investigação de doenças hereditárias que possam influenciar o desenvolvimento biológico humano, diuturnamente demonstram interesse em ter acesso à informação da ascendência civil e/ou genética, considerando o direito ao conhecimento das origens como elemento basilar da pretensão. Nesse cenário, com o intuito de privar a família adotante de constrangimento, além de evitar influenciar o crescimento do adotado no convívio sócio-afetivo, sedimentou-se entendimento doutrinário de que toda e qualquer informação sobre os pais biológicos devem permanecer em sigilo. ${ }^{3}$

Trata-se do princípio da prioridade absoluta, que rege o instituto da adoção. Princípio constitucional positivado no art. 227 da Carta Magna c/c o art. 100, inc. II da Lei 8.069/90, que estabelece medidas específicas para a proteção integral da criança e adolescente na concretização de direitos fundamentais, como à saúde, à alimentação, à educação, visando o fortalecimento do vínculo familiar saudável, assegurado pelo conjunto familiar, sociedade e poder público. ${ }^{4}$

Desse modo, pode-se utilizar interpretação análoga, para o caso do ser humano que nasce a partir da prática de reprodução assistida heteróloga, em que um terceiro doa, anonimamente, o material genético, pois, "o número de pessoas que pratica a doação de gametas poderá cair de modo expressivo frente ao constrangimento de ver sua identidade revelada". 5

\footnotetext{
${ }^{2}$ BRAUNER, Maria Claudia Crespo. Reprodução Humana Assistida e Anonimato de doadores de Gametas: $O$ Direito brasileiro frente às novas formas de paternidade. In: Tereza Rodrigues Vieira (Org.). Ensaios de Bioética e Direito. 2 ed. rev. ampl. atual. Brasíla DF: Consulex, 2012. p. 40.

${ }^{3}$ Ibidem.

${ }^{4}$ TARTUCE, Flávio. Novos princípios do Direito de Família brasileiro. Disponível em: <http://www.flaviotartuce.adv.br>. Acesso em: abr. 2015.

${ }^{5}$ BRAUNER, Maria Claudia Crespo. Reprodução Humana Assistida e Anonimato de doadores de Gametas: $O$ Direito brasileiro frente às novas formas de paternidade. In: Tereza Rodrigues Vieira (Org.). Ensaios de Bioética e Direito. 2 ed. rev. ampl. atual. Brasíla DF Consulex.2012. p. 41.
} 
A informação decorrente da análise do material genético do doador anônimo desencadeia uma série de problemas com relação ao seu acesso, pois pode incidir na vida pessoal do indivíduo que tem sua identidade genética violada, além de entrar em confronto com outros bens juridicamente tutelados do indivíduo, "incluídos os dos familiares biológicos ou coletivos relacionados à saúde e à segurança, mas também os de outra natureza, como são os econômicos". ${ }^{6}$

Da mesma forma, no âmbito privado, as empresas perceberam o quão importante é o acesso à informação, mesmo que interfira na vida íntima das pessoas, como no caso de "dispor de informação baseada em análises genéticas sobre a saúde dos candidatos a um emprego, por parte dos empresários (...)". ${ }^{7}$

Nessa senda, CASABONA sustenta que a intimidade refere-se à personalidade individual restrita, limita o controle de terceiros e qualquer forma de intervenção estatal. ${ }^{8}$ Convergentemente, "o direito à intimidade pressupõe também o direito dessa reserva ou do controle sobre terceiros", 9 conclui.

Em que pese a intimidade não signifique o mesmo que privacidade - em verdade a privacidade é um conceito que engloba a intimidade - na maioria das vezes, não podem ser interpretadas isoladamente, pois "podem carecer de significado intrínseco, mas quando enlaçadas coerentemente entre si, revelam um retrato do indivíduo que este tem direito de manter reservado". ${ }^{10}$

Nesse diapasão, o autor supra leciona que os princípios não podem ser violados pela busca de informações pessoais registradas em banco

\footnotetext{
${ }^{6}$ CASABONA, Carlos Alberto María Romeo. Do Gene ao Direito: sobre implicações jurídicas do conhecimento e intervenção no genoma humano. São Paulo: IDBCRIM, 1999. p. 56.

${ }^{7}$ CASABONA, Carlos María Romeo. O desenvolvimento do Direito diante das novas Biotecnologias. In: CASABONA, Carlos Alberto María Romeo. SÁ, Maria de Fátima Freire de (Coord). Desafios Jurídicos da Biotecnologia. Belo Horizonte: Mandamentos, 2007. p. 58.

${ }^{8}$ Idem. p. 59.

${ }^{9}$ Ibidem.

${ }^{10}$ Ibidem.
} 
de dados, "assim como podem ser atacados interesses pessoais de indivíduos", podem violar a intimidade e vida privada, refletir em outros direitos fundamentais e liberdades públicas. ${ }^{11}$

Ademais, o doutrinador refere que à medida em que a tecnologia é aprimorada, demanda mais regulação e fiscalização do Estado, que por sua vez, tem encontrado dificuldade em positivar a matéria de maneira eficiente. Por ora, a jurisprudência com relação ao sigilo de identidade do doador de gametas mantém-se adormecida, não há, no entanto, nenhuma regulação do Conselho Nacional de Justiça sobre a matéria, dessa forma, o tempo passa e as lacunas vão sendo deixadas em segundo plano. ${ }^{12} \mathrm{Em}$ contrapartida, o modelo de ordenamento jurídico americano é conhecido como "cláusula-aberta", a sociedade cria suas próprias necessidades, mas a realidade no Brasil é diferente: no Acre pode existir uma demanda, e no Chuí outra, como compatibilizar toda a regulação sem que haja esquecimento ${ }^{13}$

Uma das alternativas seria a utilização de legislações globais, como tratados internacionais, de sorte, quando não é aprovada matéria por influência de grupos dominantes (lobby), privilegiando a ciência em detrimento da sociedade. Privando-se o desenvolvimento técnico-científico pelo déficit de solidez do regramento, a tecnologia deverá adequar-se a uma regulamentação lenta. Se a lei não proíbe a doação de gametas, deve, neste caso, o exegeta interpretar os caminhos que esse ato pode ocasionar, amparando o bem de todos, na medida do possível. ${ }^{14}$

Atualmente, a reprodução assistida nacional tem guarida pelo Conselho Nacional de Medicina, que utiliza "o plano prático por meio de critérios definidos pelos próprios médicos" 15 para adoção da resolução $2.121 / 15$. Estabelece que não poderá ser publicizada a identidade do doador de gametas ao banco de sêmen. No entanto, em casos excepcionais, as

\footnotetext{
${ }^{11}$ CASABONA, Carlos María Romeo. O desenvolvimento do Direito diante das novas Biotecnologias. In: CASABONA, Carlos Alberto María Romeo. SÁ, Maria de Fátima Freire de (Coord). Desafios Jurídicos da Biotecnologia. Belo Horizonte: Mandamentos, 2007. p. 60 .

${ }^{12}$ Ibidem.

13 Ibidem.

${ }^{14}$ Ibidem.

${ }^{15}$ BRAUNER, Maria Claudia Crespo. Reprodução Humana Assistida e Anonimato de doadores de Gametas: $\mathrm{O}$ Direito brasileiro frente às novas formas de paternidade. In: Tereza Rodrigues Vieira (Org.). Ensaios de Bioética e Direito. 2 ed. rev. ampl. atual. Brasíla DF: Consulex, 2012. p. 38.
} 
informações sobre doadores podem ser divulgadas exclusivamente para médicos, resguardando-se a identidade civil do doador. ${ }^{16}$

Para isso, ao doar o material genético para a reprodução heterológa, o doador de gametas tem ciência de que será destinado para fins de gerar um ser; não se obriga à filiação, pois, não sabe quem irá receber o material genético para concepção, muito menos querer ter contato com essa pessoa. Neste caso, a obrigação de filiação é de outrem, aquele que se predispõe a manter vinculo sócio-afetivo com o concebido. ${ }^{17}$

A partir daí, surgem encargos familiares estribados na solidariedade social, objetivo fundamental previsto no art. $3^{\circ}$, inc. I da Constituição Federal, v.g., o pagamento de alimentos (art. 1694 CC). Não só pecuniários, a solidariedade também corresponde a aspectos psicológicos e afetivos, podendo, em casos específicos, o Estado amparar a família, a partir da promoção de medidas que coíbam a violência doméstica (art. $226 \S 8^{\circ}$ da Constituição Federal), por exemplo, com espeque no princípio da solidariedade familiar. ${ }^{18}$

Na mesma medida, a doação de gametas nas técnicas de procriação heteróloga não gera qualquer tipo de pretensão referente à pensão alimentícia, já que a doação é um ato de abandono do material genético, desvinculado de responsabilidade. ${ }^{19}$

Ademais, CALLIOLI entende que o sigilo do doador de gametas deve ser preservado, assegurando assim, o cultivo familiar habitual da criança, impossibilitando a influência de aspectos psicológicos, que integram a personalidade. ${ }^{20}$

A título elucidativo, ocorreu um caso recente no TJ/RS em que fora realizado pedido de registro de nascimento por casal homoafetivo de

\footnotetext{
${ }^{16}$ In: Capítulo IV, ponto 4 da Resolução do Conselho Federal de medicina. (RESOLUÇÃO CFM No 2.121/2015. Brasília, Diário Oficial da União, DF, 24 set. 2015. Disponível em: <http://www.portalmedico.org.br/resolucoes/CFM/2015/2121_2015.pdf>. Acesso em out. 2015.)

${ }^{17}$ CALLIOLI, Eugenio Carlos. Aspectos da fecundação artificial in vitro. In: CAHALI, Yussef Said; CAHALI, Francisco José (Orgs.). Famílias e Sucessões. São Paulo: Revista dos Tribunais, 2011. v. 1. p. 144.

${ }^{18}$ TARTUCE, Flávio. Novos princípios do Direito de Família brasileiro. Disponível em: <http://www.flaviotartuce.adv.br>. Acesso em: abr. 2015.

${ }^{19}$ CALLIOLI, Eugenio Carlos. Aspectos da fecundação artificial in vitro. In: CAHALI, Yussef Said; CAHALI, Francisco José (Orgs.). Famílias e Sucessões. São Paulo: Revista dos Tribunais, 2011. v. 1. p. 140.

${ }^{20}$ Ibidem.
} 
criança concebida por reprodução assistida heteróloga, com o uso do material do doador anônimo. O juízo entendeu cabível a citação do laboratório responsável pela inseminação artificial, além do doador do gameta (violando sua identidade civil), por entender que a criança tinha direito de conhecer sua ascendência genética.

Reformada a sentença, o juízo ad quem firmou entendimento de que a quebra de sigilo do doador, inviabilizaria o próprio processo de inseminação artificial, pelo desinteresse de voluntários, é consequência lógica da doação anônima a constatação de que quem disponibiliza o sêmen não tem a intenção de ser identificado, continuou a explanação em seu voto o Desembargador Luiz Felipe Brasil Santos. Além disso, complementou dizendo que há exigência expressa do Conselho Federal de Medicina de que não há possibilidade do doador ser citado no caso em tela, somente seria cabível no caso da criança querer investigar sua paternidade - por ser direito personalíssimo -, apenas ela poderia intentar a pretensão, como bem se observa na decisão de Agravo de Instrumento ${ }^{21}$ do Egrégio Tribunal de Justiça do Rio Grande do Sul.

Ademais, como bem sinalizado pelo juízo adquem, a resolução 2.013/13 determina os limites do sigilo do material genético do doador anônimo na reprodução humana heteróloga, onde as informações de seu gameta ficam resguardadas no banco de células e tecidos germinativos, sendo vedada sua publicização.

O material genético pode demonstrar características identificadoras de um ser humano, possuir informações pormenorizadas que individualizam o sujeito, vinculando-o à sua identificação genética. Diante disso,

\footnotetext{
${ }^{21}$ PEDIDO DE REGISTRO DE NASCIMENTO DEDUZIDO POR CASAL HOMOAFETIVO, QUE CONCEBEU O BEBÊ POR MÉTODO DE REPRODUÇÃO ASSISTIDA HETERÓLOGA, COM UTILIZAÇÃO DE GAMETA DE DOADOR ANÔNIMO. DECISÃO QUE ORDENOU A CITAÇÃ̃O DO LABORATÓRIO RESPONSÁVEL PELA INSEMINAÇÃO E DO DOADOR ANÔNIMO, BEM COMO NOMEOU CURADOR ESPECIAL À INFANTE. DESNECESSÁRIO TUMULTO PROCESSUAL. INEXISTÊNCIA DE LIDE OU PRETENSÃO RESISTIDA. SUPERIOR INTERESSE DA CRIANÇA QUE IMPÕE O REGISTRO PARA CONFERIR-LHE O STATUS QUE JÁ DESFRUTA DE FILHA DO CASAL AGRAVANTE, PODENDO OSTENTAR O NOME DA FAMÍLIA QUE LHE CONCEBEU. [...] DERAM PROVIMENTO. UNÂNIME. (Agravo de Instrumento $N^{\circ}$ 70052132370, Oitava Câmara Cível, Tribunal de Justiça do RS, Relator: Luiz Felipe Brasil Santos, Julgado em: 04 abr. 2013). (Grifos dos Autores)
} 
no entendimento de CORREAA, deve prevalecer o direito de sigilo de identidade genética do ser humano. ${ }^{22}$

Na mesma medida, a Declaração Universal sobre o Genoma Humano (DUGH), assegura a preservação da identidade genética do indivíduo, privando-o de eventuais investigações a quaisquer dados genéticos, seja para fins de pesquisa científica ou para identificação genética.

Além disso, havendo violação no sigilo das informações genéticas, o doador poderia pleitear a reparação dos danos sofridos em decorrência de intervenção ilícita que tenha acometido seu genoma, amparado pela DUGH em seu artigo 8, senão vejamos:

Art. 8: Cada indivíduo terá direito, conforme a legislação nacional ou internacional, à justa indenização por qualquer dano sofrido resultante, direta ou indiretamente, de intervenção sobre seu genoma.

$\mathrm{O}$ direito ao anonimato do doador de gametas trata-se de direito fundamental subjetivo, análogo ao direito fundamental à privacidade insculpido no artigo $5^{\circ}$, inciso $\mathrm{X}$, da Constituição Federal, que regulamenta ser inviolável à intimidade e à vida privada, cabendo direito à indenização decorrente da violação.

Os fundamentos que embasam o sigilo de identidade genética dos doadores estão visualizados na contemplação da estruturação sócio-afetiva pré-constituída a partir do embrião oriundo do gene do doador, que insere o rebento em um conjunto familiar. ${ }^{23}$

Reitera-se a importância do princípio da afetividade, sobrepondo-se ao critério biológico, quebrando paradigmas sociais e, trazendo, nas palavras de TARTUCE: "a concepção da família de acordo com o meio social". Hoje, a partir da I jornada de Direito Civil, em seu enunciado $\mathrm{n}^{\mathbf{o}}$ 103, "o CC reconhece, no art. 1.593, outras espécies de parentesco civil (...) no vinculo parental proveniente das técnicas de reprodução assistida

${ }^{22}$ CÔRREA, Adriana Espíndola. O corpo digitalizado: banco de dados genéticos e sua regulação jurídica. Florianópolis, SC: Conceito Editorial, 2010. p. 147.

${ }^{23}$ BRAUNER, Maria Claudia Crespo. Reprodução Humana Assistida e Anonimato de doadores de Gametas: O Direito brasileiro frente às novas formas de paternidade. In: Tereza Rodrigues Vieira (Org.). Ensaios de Bioética e Direito. 2 ed. rev. ampl. atual. Brasíla DF: Consulex, 2012. p. 43. 
heteróloga relativamente ao pai (ou mãe) que não contribuiu com seu material fecundante (...)". ${ }^{24}$

Por outro lado, no entendimento de POUSSON-PETIT, o debate sobre o direito de investigação genética seria uma espécie de individualismo contemporâneo e, tanto na adoção como na reprodução heteróloga, a discussão constitui interpretação paradoxal; há, na verdade, um problema que inexiste, pois a identidade deveria ser aquela adquirida pelo vínculo sócio-afetivo. ${ }^{25}$

A doação de material genético é o ato de ceder a outrem, sem qualquer responsabilidade ou cláusula de retorno e arrependimento. É um ato benevolente de vontade, medida de contemplação humanitária, que priva a filiação criatura-criador, sob a exegese do princípio do anonimato. 26

Frise-se, a consanguinidade não tem o condão de abranger, invariavelmente, à filiação, a despeito de possuir importância intrínseca ponderável, defronte ao liame genético para estabelecer situações específicas de filiação, submetendo-se, por vezes, ao estabelecimento de laços afetivos, criando-se assim um parentesco. ${ }^{27}$

Admitindo, porém, para a sua primazia, o entrelaçar de componentes abstratos que factualmente constatam a ação volitiva do progenitor em fruir da circunstância de ser pai ou mãe.

A partir da doação do material genético, o doador não possuiria qualquer tipo de relação com a mãe ou com o concebido, sendo apenas um ajudante no processo, por essa razão, haveria a possibilidade do sigilo de identidade do doador ser resguardado.

A questão pode ser ainda examinada por dois vieses, pelo controle sobre o fluxo dos dados genéticos pessoais, ou sob a perspectiva da

\footnotetext{
${ }^{24}$ TARTUCE, Flávio. Novos princípios do Direito de Família brasileiro. Disponível em: <http://www.flaviotartuce.adv.br>. Acesso em: abr. 2015.

${ }^{25}$ BRAUNER, Maria Claudia Crespo. Reprodução Humana Assistida e Anonimato de doadores de Gametas: $\mathrm{O}$ Direito brasileiro frente às novas formas de paternidade. In: Tereza Rodrigues Vieira (Org.). Ensaios de Bioética e Direito. 2 ed. rev. ampl. atual. Brasíla DF: Consulex, 2012. p. 43.

${ }^{26}$ LEITE, Eduardo de Oliveira. Procriações artificiais e o direito: aspectos médicos, religiosos, psicológicos, éticos e jurídicos. São Paulo, Ed. Revista dos Tribunais, 1995. p. 145. ${ }^{27}$ CABRAL, Hildeliza Lacerda Tinoco Boechat; CAMARDA, Dayane Ferreira. Intimidade versus Origem Genética: A ponderação de interesses aplicada à reprodução Assistida Heteróloga. Disponível em: <www-antigo.mpmg.mp.br/portal/public/interno/arquivo/id/32427>. Acesso em: dez. 2014.
} 
garantia da confidencialidade desses dados, mas ambos são aspectos que se complementam, na medida em que são mecanismos de proteção do direito à privacidade. ${ }^{28}$

Logo, o ânimo do individuo ao pretender filiar-se a alguém demonstra uma vontade subjetiva emanada do direito ao planejamento familiar, disposto na Constituição Federal, ${ }^{29}$ resguardado pela paternidade responsável e a dignidade da pessoa humana.

Destarte, o acesso aos dados genéticos do doador, salvo melhor juízo, arrazoa-se inviolável, inerente à esfera íntima do indivíduo, impossibilitando que o genoma humano se torne alvo de investigação, mesmo pelo desejo do descendente, fruto da inseminação assistida heteróloga, ao querer descobrir a identidade do pai biológico. O mesmo ocorre para o doador que deseja conhecer os seres gerados de seu material genético. Da mesma forma, os pais que poderiam demandar por auxilio dos filhos quando em situação financeira ou de saúde precárias.

Assim sendo, o vínculo socioafetivo, embora desnudo de ascendência genética, representa uma condição real que necessita ser analisada minuciosamente pelo intérprete. Aparentemente, a paternidade decorrente da boa-fé, note-se, no agir dentro da legalidade, sem intenções secundárias, deve ter amparo no direito de família. E o sigilo, nas hipóteses de reprodução heteróloga, torna-se importante nesse processo, para garantir a solidez do grupo familiar.

\section{DIREITO À IDENTIDADE PESSOAL}

A identidade representa o modo como o ser humano interage com as pessoas em geral, a forma como ele é visto pela sociedade, a posição do

\footnotetext{
${ }^{28}$ LEITE, Eduardo de Oliveira. Procriações artificiais e o direito: aspectos médicos, religiosos, psicológicos, éticos e jurídicos. São Paulo, Ed. Revista dos Tribunais, 1995. p. 148. ${ }^{29} \mathrm{O}$ artigo $226, \S 7^{\circ}$, da Constituição Federal dispõe: “A família, base da sociedade, tem especial proteção do Estado (...) $\S 7^{\circ}$ - Fundado nos princípios da dignidade da pessoa humana e da paternidade responsável, o planejamento familiar é livre decisão do casal, competindo ao Estado propiciar recursos educacionais e científicos para o exercício desse direito, vedada qualquer forma coercitiva por parte de instituições oficiais ou privadas." (BRASIL. Constituição (1988). Constituição da República Federativa do Brasil. Diário Oficial da União, Brasília, DF, 5 out. 1988. Disponível em: <http://www.planalto.gov.br/ccivil_03/constituicao/constituicaocompilado.htm>. Acesso em: mai. 2015.)
} 
seu "eu" pessoa em posição de destaque no convívio social. O Estado Democrático de Direito possibilita uma sociedade pluralista, ao fim e ao cabo de perscrutar diferentes formas de identidade, em constante transformação, estando integrada em "uma rede de interlocução e interdependência", ${ }^{30}$

Na perspectiva democrática de direito, é necessário que a norma jurídica resguarde iguais liberdades a todos os indivíduos que constituem essa rede de interlocução e interdependência, a fim de que possam, no exercício da sua autonomia privada, fazer escolhas e definir os conteúdos da sua identidade pessoal. ${ }^{31}$

O princípio da autonomia privada compreende-se no poder que o indivíduo detém em regulamentar seus interesses, mantendo estreita relação com o princípio da não intervenção ou da liberdade, instituído pelo Direito de Família, com previsão no art. 1.513 do Código Civil, sendo "defeso a qualquer pessoa de direito público ou direito privado interferir na comunhão da vida instituída pela família", ressalvados os casos em que o Ente estatal deve "propiciar recursos educacionais e financeiros para o exercício desse direito (planejamento familiar), vedado qualquer tipo de coerção por parte de instituições privadas ou públicas" (art. $1.565, \S 2^{\circ}$ do Código Civil). ${ }^{32}$

Segundo TEIXEIRA, a essência da identidade se estrutura pela divisão de um processo histórico e outro não histórico. Aquele representa as pré-compreensões e auto compreensões compartilhadas entre os indivíduos na sociedade em que habitam. Portanto, quando o individuo pactua com alguma religião, que veda algumas intervenções médicas, esse mero

\footnotetext{
${ }^{30}$ TEIXEIRA, Ana Carolina Brochado; MOUREIRA, Diogo Luna. A identidade genética e seus reflexos no Direito brasileiro. In: CASABONA, Carlos Maria Romeo, SÁ, Maria de Fátima Freire de. Direito Biomédico: Brasil-Espanha. Belo Horizonte: Ed. PUC Minas, 2011. p. 118.

${ }^{31}$ Ibidem.

${ }^{32}$ TARTUCE, Flávio. Novos princípios do Direito de Família brasileiro. Disponível em: <http://www.flaviotartuce.adv.br>. Acesso em: abr. 2015.
} 
ato de escolha deve ser entendido como um componente afirmativo da identidade, referente ao foro íntimo do indivíduo em uma perspectiva moral e cultural. ${ }^{33}$

Já o processo não-histórico, diz respeito à forma como o indivíduo é visto aos olhos da sociedade, isto é, refere-se à constante interação do indivíduo no estado de interdependência, na representação de sua personalidade. ${ }^{34}$ Contudo, o autor assevera:

Identidade genética não se confunde com a identidade produto do processo histórico e não-histórico, construído pela pessoa em sua esfera de (co)vivência, mas pode nela intervir, na medida em que a utilização desregrada de informações genéticas pode influenciar na relação de pessoa com os demais indivíduos com quem interage na rede de interlocução. ${ }^{35}$

A identidade no mundo contemporâneo também pode ser entendida como intersubjetividade, ou seja, o "eu" pessoa representado no outro enquanto inserido em uma rede de interlocução. ${ }^{36}$

Por isso, PEREIRA indaga que as normas jurídicas não podem condicionar a forma como deve ser atribuída à identidade, pois acaba interferindo na autonomia privada. Tanto é que cada indivíduo constrói a sua própria identidade. $\mathrm{O}$ direito tem o dever de restringir o necessário para garantir a autonomia do indivíduo. ${ }^{37}$

Até então, a identidade era entendida como um estado de aparência, mas em decorrência da crescente evolução da tecnociência médica, em

\footnotetext{
33 TEIXEIRA, Ana Carolina Brochado; MOUREIRA, Diogo Luna. A identidade genética e seus reflexos no Direito brasileiro. In: CASABONA, Carlos Maria Romeo, SÁ, Maria de Fátima Freire de. Direito Biomédico: Brasil-Espanha. Belo Horizonte: Ed. PUC Minas, 2011. p. 116.

${ }^{34}$ Ibidem.

35 TEIXEIRA, Ana Carolina Brochado; MOUREIRA, Diogo Luna. A identidade genética e seus reflexos no Direito brasileiro. In: CASABONA, Carlos Maria Romeo, SÁ, Maria de Fátima Freire de. Direito Biomédico: Brasil-Espanha. Belo Horizonte: Ed. PUC Minas, 2011. p. 118.

${ }^{36}$ Idem. 116.

${ }^{37}$ PEREIRA, Renata Braga da Silva. DNA: Análise BioJurídica da Identidade Humana. In: BARBOSA, Heloisa Helena, BARRETTO, Vicente de Paulo. Temas de Biodireito e Bioética. Rio de Janeiro: Renovar, 2001. p. 296.
} 
especial as técnicas de engenharia genética possibilitaram a identificação do ser humano pela composição genética, "hoje identidade é contextualmente deslocada daquilo que se apresenta para aquilo que se tem biologicamente, como é o caso dos dados genéticos". 38

A partir do material genético é possível a localização de dados biográficos que auxiliam na identificação da ascendência genética do indivíduo. Essa possibilidade contribui para uma fervorosa discussão acerca de seus limites na interferência da práxis social. ${ }^{39}$

Por isso, o direito à privacidade serve como princípio basilar para o controle das informações pessoais e genéticas do individuo. Como bem leciona MOUREIRA:

$\mathrm{Na}$ sociedade da informação tendem a prevalecer definições funcionais da privacidade de que, de diversas formas, fazem referência à possibilidade de um sujeito conhecer, controlar, endereçar, interromper o fluxo das informações a ele relacionadas. Assim, a privacidade pode ser definida mais precisamente, em uma primeira aproximação, com o direito de manter o controle sobre as próprias informações. ${ }^{40}$

No entanto, a partir do desenvolvimento tecnológico, o princípio da privacidade foi paulatinamente perdendo seu caráter absoluto, o seu animus de "direito a ser deixado só", passando a possibilitar sua relativização. ${ }^{41}$

\footnotetext{
38 TEIXEIRA, Ana Carolina Brochado; MOUREIRA, Diogo Luna. A identidade genética e seus reflexos no Direito brasileiro. In: CASABONA, Carlos Maria Romeo, SÁ, Maria de Fátima Freire de. Direito Biomédico: Brasil-Espanha. Belo Horizonte: Ed. PUC Minas, 2011. p. 116.

${ }^{39}$ Idem. 117.

${ }^{40}$ Ibidem.

41 TEIXEIRA, Ana Carolina Brochado; MOUREIRA, Diogo Luna. A identidade genética e seus reflexos no Direito brasileiro. In: CASABONA, Carlos Maria Romeo, SÁ, Maria de Fátima Freire de. Direito Biomédico: Brasil-Espanha. Belo Horizonte: Ed. PUC Minas, 2011.p. 118.
} 
O reconhecimento da identidade propõe "garantir aquilo que identifica cada pessoa como indivíduo, singular e irredutível”. ${ }^{42}$ Em suma, a identidade tem um caráter pleno e subjetivo, similarmente entendida pela identificação da origem pessoal de cada individuo, ou seja, "seu direito à historicidade pessoal", ${ }^{43}$

O Direito Francês, por exemplo, acolhe um posicionamento limitado, no que pertine à divulgação da identidade do doador de gametas. É cediço o entendimento de que não pode ser divulgado qualquer conteúdo que possibilite a identificação do doador anônimo, nem mesmo a do receptor, inclusive "sendo vedado ao doador e receptor o acesso às informações que permitam a identificação do outro". ${ }^{44}$ Com exceção de situações terapêuticas, em que somente o médico poderá ter o acesso às informações genéticas, restringido o repasse para terceiros. ${ }^{45}$

O direito ao sigilo da origem pessoal, no dizer de GAMA:

(...) se justifica notadamente em razão de se verificar, tradicionalmente na vida social, tratamento social discriminatório e estigmatizante às pessoas que não tem origem consanguínea dos seus pais, o que a Constituição de 1988 , no seu artigo $227, \S 6^{\circ}$, proíbe perempetoriamente no direito brasileiro. ${ }^{46}$

A redação do regramento constitucional supra equipara-se a previsão contida no art. 1.596 do Código Civil, consagrando, ambos, o princípio da igualdade entre filhos e, em última análise, a concretização da isonomia constitucional, prevista no caput do art. $5^{\circ}$ da Constituição Federal, que, a partir do Direito Civil-Constitucional, resguarda a igualdade no con-

\footnotetext{
42 OTERO, Paulo. Personalidade e identidade pessoal e genética do ser humano: um perfil constitucional da bioética. Coimbra Almedina, 1999. apud. p. 147. p. 64

${ }^{43}$ Ibidem. 65.

${ }^{44}$ GAMA, Guilherme Calmon Nogueira da. A nova filiação: o biodireito e as relações parentais: o estabelecimento da parentalidade-filiação e os efeitos jurídicos da reprodução assistida heteróloga. Rio de Janeiro: Renovar, 2003. p. 902

45 Ibidem.

${ }^{46}$ GAMA, Guilherme Calmon Nogueira da. A nova filiação: o biodireito e as relações parentais: o estabelecimento da parentalidade-filiação e os efeitos jurídicos da reprodução assistida heteróloga. Rio de Janeiro: Renovar, 2003. p. 902
} 
vívio familiar, passando a integrar tanto filhos adotivos como os concebidos por procriação artificial, não havendo qualquer distinção fático-jurídica. ${ }^{47}$

Ademais, GAMA sustenta que o anonimato do doador deve prevalecer até para que a criança tenha totais condições de convivência com os familiares sócio-afetivos. O sigilo do doador tem por finalidade a proteção dos interesses da criança, "impedindo qualquer tratamento odioso no sentido de descriminação e estigma relativamente à pessoa adotada ou fruto da procriação assistida heteróloga". ${ }^{48}$

Além disso, o Estatuto da criança e do Adolescente (ECA) referendou dispositivo que privilegia o melhor interesse da criança e adolescente, impossibilitando que qualquer indivíduo venha disponibilizar de informações de parentesco, no caso de adoção, sendo, consequentemente, vedada a publicização da identidade paterna/materna do adotado. Nesse sentido:

Os artigos 16 e 17, do ECA, asseguram à criança a liberdade, a participação da vida familiar e comunitária sem discriminação, o respeito incluindo a preservação da imagem e da identidade da criança e do adolescente. Desse modo, de maneira bastante pormenorizada, o artigo 47, do ECA, estabelece o conjunto de providências que devem ser tomadas na lavratura do novo registro de nascimento do adotado, com o cancelamento do anterior, sem que seja possível fazer qualquer referência a origem da filiação. Há, apenas, a exceção prevista no artigo 47, $\S 4^{\circ}$, do ECA, quanto à expedição de certidão para salvaguarda de direitos, mediante determinação judicial. ${ }^{49}$

\footnotetext{
47 TARTUCE, Flávio. Novos princípios do Direito de Família brasileiro. Disponível em: <http://www.flaviotartuce.adv.br>. Acesso em: abr. 2015.

${ }^{48}$ GAMA, Guilherme Calmon Nogueira da. A nova filiação: o biodireito e as relações parentais: o estabelecimento da parentalidade-filiação e os efeitos jurídicos da reprodução assistida heteróloga. Rio de Janeiro: Renovar, 2003. p. 902.

${ }^{49}$ GAMA, Guilherme Calmon Nogueira da. A nova filiação: o biodireito e as relações parentais: o estabelecimento da parentalidade-filiação e os efeitos jurídicos da reprodução assistida heteróloga. Rio de Janeiro: Renovar, 2003. p. 901.
} 
Porém, é forçoso considerar entendimento extensivo do que preceitua o artigo 47 do ECA, pois "as disposições e regras ali tratadas se referem ao procedimento judicial e seus efeitos na esfera registraria".50 Como não há dispositivo que normatize como o Estado deve prestar assistência na reprodução artificial - na adoção: artigo $227, \S 5^{\circ}, \mathrm{CF}$-, seria viável considerar o acesso judicial? Nesse sentido:

(...) a própria distinção que existe entre a adoção estatutária e a adoção civil no que tange aos requisitos formais, a demonstrar a impossibilidade de adotar os critérios relacionados à interpretação extensiva para aplicação do artigo 47, do ECA, à procriação heteróloga. Contudo, a analogia é perfeitamente cabível naquilo que se refere ao sigilo do procedimento médico e ao anonimato das pessoas envolvidas, inclusive a doador. ${ }^{51}$

Por outro lado, GAMA sustenta que o sigilo da identidade civil do doador, deve ser entendido como tutela absoluta a qualquer pessoa, excetuado os casos em que a questão se refere à própria criança concebida por reprodução heteróloga. ${ }^{52}$

Nesse diapasão, no relacionamento social, as pessoas dependem que o ordenamento jurídico assegure a manutenção de valores básicos, para que a sociedade consiga buscar seus anseios. No caso em apreço, o sistema jurídico deve amparar valores privilegiando aspectos intrínsecos e extrínsecos da personalidade humana na promoção da inserção social do indivíduo.

Com isso, devem ser analisados outros aspectos que influenciam a integridade moral e/ou a psique (inconsciente) do indivíduo, comportando a história de suas origens, sua imagem sobre si mesmo, sua identidade familiar, sociocultural, presentes na própria trajetória de vida do indivíduo, visando, em última análise, o amparo à identidade pessoal em prol de privilegiar o resguardo do Direito à Personalidade em sua completude.

Embora muitos defendam que o direito ao anonimato tem caráter absoluto, tal constatação poderá, salvo melhor juízo, ser relativizada em

\footnotetext{
${ }^{50}$ Idem. p. 902.

${ }^{51}$ Idem. p. 903.

${ }^{52}$ Ibidem.
} 
casos em que a criança concebida por reprodução artificial, corra riscos reais de doenças hereditárias, nesse sentido:

(...) Não há como reconhecer que o anonimato do doador possa prevalecer perante a iminente lesão à vida ou à higidez físico-corporal da pessoa que foi gerada com o material fecundante do primeiro. Ainda que se fundamente $o$ anonimato com base na intimidade e privacidade do doador, logicamente que tal direito fundamental deverá ceder quando colocado em confronto com o direito à vida e, nele inserido, $\mathrm{o}$ direito à vida de outra pessoa. ${ }^{53}$

Por outro lado, FERREIRA sustenta que o direito à identidade pessoal, a partir da historicidade, deve ter guarida até pelo aspecto do autoconhecimento, lembrando que não há qualquer possibilidade de filiação. Em que pese seja hialino, que haja uma proximidade genética entre o doador e a criança gerada, para fins legais, não possuirão qualquer vinculo, mesmo que um dos envolvidos requeira. ${ }^{54}$

$\mathrm{Na}$ técnica de reprodução heteróloga, para que se caracterize o direito de filiação, deve ser analisado o critério sócio-afetivo, como visto anteriormente, no qual o direito à informação da ascendência genética é de suma importância, para que a criança tenha condições de saber de onde veio e para onde vai, ou seja, compreender sua própria existência por meio de suas origens genéticas, para então entender e edificar os laços afetivos com seus verdadeiros pais. ${ }^{55}$

$\mathrm{O}$ direito de conhecer a realidade de sua própria historicidade, transvalora-se em tutela fundamental regida pelo direito da personalidade.

${ }^{53}$ GAMA, Guilherme Calmon Nogueira da. A nova filiação: o biodireito e as relações parentais: o estabelecimento da parentalidade-filiação e os efeitos jurídicos da reprodução assistida heteróloga. Rio de Janeiro: Renovar, 2003. p. 903.

${ }^{54}$ FERREIRA, A. D. D. O direito de conhecer a origem genética e o anonimato do doador. 2013. 140f. Diss. (Mestrado em Direito) - Fac. De Direito, PUCRS, Porto Alegre. 2013. p. 64.

${ }^{55}$ ALMEIDA, Silmara Juny de Abreu Chinelato e. Reprodução humana assistida: aspectos civis e bioéticos. Tese apresentada ao concurso à Livre-Docência do Departamento de Direito Civil da Faculdade de Direitos da Universidade de São Paulo: Universidade de São Paulo, set. 2000. p. 173. 
Nos ensinamentos de GAMA, a negativa do doador anônimo em não querer ter sua identidade revelada, pelo argumento de que viola o direito à intimidade, deve ser critério preponderante para qualquer pessoa, menos, é claro, para o concebido por reprodução heteróloga. ${ }^{56}$

Desse modo, ALMEIDA sustenta que a identidade pessoal "não é exaustiva, abrangendo também a origem genética que muito explicará sobre as raízes, a história pessoal do titular. São novas vertentes da identidade, no mundo da tecnologia". 57

Segundo entendimento de OTERO, a identidade pessoal é classificada em dois grupos; são eles: a dimensão absoluta, onde cada indivíduo possuí uma identidade subjetiva, vista por si mesmo, é uma característica pessoal única e indivisível, que o diferencia do resto da sociedade. Além da identidade absoluta, o autor menciona a dimensão relativa da identidade, objeto do trabalho, que nada mais é do que um direito à historicidade pessoal, a busca pela ancestralidade do indivíduo, em última análise, segmenta o direito à ascendência genética. ${ }^{58}$

A identidade pessoal relativa confere a subjetividade própria, conduzida pela história pessoal, transcendendo no campo da genética, é a memória do seu eu, quando exteriorizado com a sociedade. São características que individualizam cada ser humano, como o nome, o apelido, o convívio social, essa identidade pessoal desencadeia o direito à historicidade de suas origens pessoais, podendo incidir inclusive no seu patrimônio genético, no caso da pessoa ser concebida por reprodução assistida heteróloga, essa historicidade no sentido lato, representa "o direito de cada ser humano conhecer a forma como foi gerado". 59

\footnotetext{
56 GAMA, Guilherme Calmon Nogueira da. A nova filiação: o biodireito e as relações parentais: o estabelecimento da parentalidade-filiação e os efeitos jurídicos da reprodução assistida heteróloga. Rio de Janeiro: Renovar, 2003. p. 1026.

${ }^{57}$ ALMEIDA, Silmara Juny de Abreu Chinelato e. Reprodução humana assistida: aspectos civis e bioéticos. Tese apresentada ao concurso à Livre-Docência do Departamento de Direito Civil da Faculdade de Direitos da Universidade de São Paulo: Universidade de São Paulo, set. 2000. p. 174.

58 OTERO, Paulo. Personalidade, Identidade Pessoal e Genética do ser humano: um perfil constitucional da bioética. São Paulo: Coimbra Almedina, 1999. p. 75.

${ }^{59}$ OTERO, Paulo. Personalidade, Identidade Pessoal e Genética do ser humano: um perfil constitucional da bioética. São Paulo: Coimbra Almedina, 1999. p. 77.
} 
Ademais, OTERO entende que qualquer regramento que afaste a possibilidade do indivíduo em conhecer suas origens genéticas, como qualquer forma de segredo ou sigilo que impossibilite isso, deve ser considerado inconstitucional. ${ }^{60}$

Além disso, DINIZ sustenta que para os casos em que o indivíduo necessite conhecer origens genéticas, imperioso que o Estado tutele esse direito, avalizando se caberá ou não a revelação da identidade de seus genitores, no caso concreto. ${ }^{61}$ Nesse sentido:

(...) com a fertilização assistida, no porvir, poder-se-á ter uma legião de seres humanos feridos na sua constituição psíquica e orgânica, E, além disso, o anonimato do doador do material fertilizante traz em si a possibilidade de incesto e de degeneração da espécie humana. ${ }^{62}$

Nessa premissa, verifica-se que todo e qualquer indivíduo poderia saber quem são seus verdadeiros pais biológicos, como componente do Direito à personalidade que o é. Em contrapartida, deve-se atentar que "os doadores não podem ficar reduzidos na sua dignidade a uma simples fixa de arquivos". ${ }^{63}$

De outro norte, perceba-se que não há um rol taxativo de Direitos da personalidade, isto é, há tipicidade aberta no Direito da personalidade em função do Artigo 12 do Código Civil. Evidente que haverá outras situações que ensejam o resguardo do Direito à personalidade, e nisso visualiza-se uma constatação caótica: as futuras gerações não têm direito à Bioética em sua integralidade.

Nesse diapasão, LOBO salienta que ninguém pode privar o indivíduo de ter uma vida sem um eixo fundamental, isto é, uma "biparentalidade de filiação"; logo, a reprodução artificial não seria cabível sem a adoção de um pai e uma mãe, isso porque, em técnicas que possibilitem o uso

\footnotetext{
${ }^{60}$ Idem. p. 75.

${ }^{61}$ DINIZ, Maria Helena. O Estado do Biodireito. 2. Ed. aum. e atual. de acordo com o novo Código Civil (Lei n. 10.406, de 10-01-2002). São Paulo: Saraiva, 2002. p. 454.

${ }^{62}$ Ibidem.

${ }^{63}$ Ibidem.
} 
de material genético por doadores diferentes, por exemplo, dificultaria o conhecimento da ascendência genética dos genitores. ${ }^{64}$

No entanto, salienta-se que pela atual redação do art. $1^{\circ}$ do Código Civil, não mais se utiliza o termo homem, e sim pessoa, diversamente da previsão contida no art. $2^{\circ}$ do Código Civil de 1916, restando-se hialino que não há distinção em decorrência do sexo. ${ }^{65}$

Além disso, da mesma forma como existe igualdade entre filhos, a constituição referenda o princípio da igualdade entre cônjuges e companheiros, a partir do casamento ou união estável, com arrimo no art. $226 \S \S$ $3^{\circ}$ e $5^{\circ}$ da Constituição Federal. ${ }^{66}$

Convergentemente, refere-se o princípio da igualdade na chefia familiar, com amparo nos artigos. $226 \S 5^{\circ} / 227 \S 7^{\circ} \mathrm{CF} / 88 \mathrm{c} / \mathrm{c}$ artigos. 1.566, inc. III e IV/1.634 do Código Civil, consagrando o conceito de família democrática, extirpando o entendimento que outrora se propunha o que TARTUCE chama de "patriarcalização do Direito de Família", cuja figura do homem possuía o controle familiar. ${ }^{67}$

Por fim, o direito ao conhecimento das origens pessoais, enquanto aspecto pertencente à identidade pessoal do indivíduo se relaciona à vedação da privação desarrazoada da família, ao passo que sua constituição deve vir acompanhada de condições mínimas para desenvolvimento da personalidade do indivíduo, na promoção de um convívio familiar saudável.

\section{CONFLITO DE PROBLEMATIZAÇÃO: SIGILO VERSUS IDENTIDADE}

Já é consabido que na legislação vigente não se encontra respaldo para estudo aprofundado acerca da reprodução humana assistida; a par dessas considerações, necessário ater-se às legislações estrangeiras, para melhor delimitação do posicionamento atinente ao tema.

\footnotetext{
${ }^{64}$ LOBO, Paulo Luiz Netto. Direito ao Estado de filiação e Direito à Origem Genética. Disponível em: <https://www2.cjf.jus.br/ojs2/index.php/revcej/article/viewFile/633/813>. Acesso em: dez. 2014.

${ }^{65}$ TARTUCE, Flávio. Novos princípios do Direito de Família brasileiro. Disponível em: <http://www.flaviotartuce.adv.br>. Acesso em: abr. 2015.

${ }^{66}$ Ibidem.

${ }^{67}$ Ibidem.
} 
Inicialmente, na Grécia e no Reino Unido constata-se similaridade acerca do tema, eis que incabível o reconhecimento da identidade genética por parte do filho em ambas as legislações. No entanto, é assegurado o conhecimento de suas informações genéticas junto ao banco de reprodução humana assistida. ${ }^{68}$

Na legislação alemã, em conformidade com o que refere GAMA, a criança tem direito de saber sua historicidade biológica, sendo que todos seus dados genéticos são centralizados nos centros de reprodução humana. ${ }^{69}$

No Direito espanhol:

Somente é permitida a revelação da identidade do doador quando existente comprovado risco de vida para o filho, ou quando necessária à punição de natureza penal, garantida, em qualquer caso, a restrição ao uso dos dados, que não poderão ser tornados públicos sem que isso implique, em qualquer hipótese, determinação legal de filiação. ${ }^{70}$

A partir do Direito sueco, constata-se que a criança tem direito de pleitear sua ascendência genética e biológica assim que completar todos os requisitos para o pleiteio, incluindo a identidade do doador. ${ }^{71}$ Da mesma forma na Suíça, atingida a maturidade necessária, a criança pode buscar informações atinentes ao doador, advertida sua "legitimidade para intentar ação de reconhecimento de paternidade (art. 23)". ${ }^{72}$

A legislação francesa somente admite o levantamento do anonimato em caso de necessidade terapêutica e, mesmo assim, reservada aos médicos do doador e do receptor, não admitindo, em nenhuma hipótese, a

\footnotetext{
${ }^{68}$ AGUIAR, M. Direito à Filiação e Bioética. Rio de Janeiro: Forense, 2005. p. 127.

${ }^{69}$ GAMA, Guilherme Calmon Nogueira da. A nova filiação: o biodireito e as relações parentais: o estabelecimento da parentalidade-filiação e os efeitos jurídicos da reprodução assistida heteróloga. Rio de Janeiro: Renovar, 2003. p. 296.

${ }^{70}$ AGUIAR, M. Direito à Filiação e Bioética. Rio de Janeiro: Forense, 2005. p. 133.

${ }^{71}$ GAMA, Guilherme Calmon Nogueira da. A nova filiação: o biodireito e as relações parentais: o estabelecimento da parentalidade-filiação e os efeitos jurídicos da reprodução assistida heteróloga. Rio de Janeiro: Renovar, 2003. p. 300.
}

${ }^{72}$ AGUIAR, M. Direito à Filiação e Bioética. Rio de Janeiro: Forense, 2005. p. 147. 
divulgação de tais informações a outras pessoas. ${ }^{73}$ Oportuno mencionar que:

(...) atualmente, a comunidade jurídica francesa aspira ao alcance da implementação do direito ao conhecimento da identidade dos 'pais' genéticos, sem a imposição de qualquer tipo de ressalva. ${ }^{74}$

Em última análise, a partir das legislações trazidas como exemplos, constata-se que a maioria delas defende o pleiteio do exercício do direito da historicidade genética e biológica, atingindo a plenitude do exercício do direito à personalidade da criança nas técnicas de Reprodução Humana Assistida Heteróloga. ${ }^{75}$

Em contrapartida, vale ressaltar, que no Brasil, o foco central da doutrina permeia basicamente quanto à admissão do conhecimento das origens do concebido, por ser amparado em um direito fundamental, porém não tem se discutido se esse direito resguardará tão somente os dados genéticos do doador ou permitirá assegurar inclusive a sua própria identidade civil. ${ }^{76}$

Analisando atidamente ao resguardo do direito à identidade do concebido, verifica-se, em conformidade com que doutrina BARACHO, que se valer apenas do exercício do conhecimento dos dados genéticos acaba obstaculizando o próprio resguardo ao Direito da personalidade em sua integralidade, pois “A consagração de um direito a identidade genética

\footnotetext{
${ }^{73}$ GAMA, Guilherme Calmon Nogueira da. A nova filiação: o biodireito e as relações parentais: o estabelecimento da parentalidade-filiação e os efeitos jurídicos da reprodução assistida heteróloga. Rio de Janeiro: Renovar, 2003. p. 901.

74 FAVA. Juliane Carvalho de Souza. A reprodução humana assistida e a tutela jurisdicional da identidade genética. 2009. 98f. Diss. (Mestrado em Direito) - Fac. De Direito, UNIPAR, Umuarama. 2009. p.41. In: FURKEL apud DONIZETTI, 2007. p. 133. 75 FAVA. Juliane Carvalho de Souza. A reprodução humana assistida e a tutela jurisdicional da identidade genética. 2009. 98f. Diss. (Mestrado em Direito) - Fac. De Direito, UNIPAR, Umuarama. 2009. p. 42.

${ }^{76}$ Ibidem.
} 
aponta para o entendimento de que o genoma humano seja não só inviolável, como também irrepetível, para que seja basicamente fruto do acaso e não da heterodeterminação", ${ }^{77}$

A toda evidência, como bem disserta MORAES, o amparo do direito da personalidade, quando analisado em sua totalidade, enseja a tutela da própria dignidade da pessoa humana, possibilitando a oportunidade do concebido de ter a ciência da verdadeira identidade de seus progenitores. ${ }^{78}$

Em vista disso, o doutrinador GAMA conclui que a informação a respeito do procedimento médico e da identidade do doador somente permite o pleno conhecimento da história da sua vida sob o prisma biológico que pode, perfeitamente, auxiliar a pessoa a compreender várias manifestações físicas, psíquicas ou comportamentais que até então desconhecia. ${ }^{79}$ Neste caso, a necessidade de conhecer a identidade civil deveria advir, salvo melhor juízo, de um direito de pleno desenvolvimento da personalidade, a partir da humanização do ser - afastando a antiga visão coisificada - onde o direito de personalidade da criança abarcaria o conhecimento de genótipo, fenótipo e a existência em si de seu progenitor.

O conhecimento sobre apenas os dados genéticos, não concede à criança a identidade plena do doador, de modo que "a ciência quanto ao patrimônio genético não é apta a trazer a certeza e a transparência que se pretende quando se olha para um rosto e se consegue enxergar nele os traços característicos da pessoa fruto das técnicas de reprodução assistida heteróloga", sendo o escopo para o pleiteio do direito da personalidade atrelado a questionamentos terapêuticos. Justamente por isso, o progenitor representa a insubstituível resposta para a indagação, de quem somos e de onde viemos. ${ }^{80}$

77 FAVA. Juliane Carvalho de Souza. A reprodução humana assistida e a tutela jurisdicional da identidade genética. 2009. 98f. Diss. (Mestrado em Direito) - Fac. De Direito, UNIPAR, Umuarama. 2009. p. 42.

${ }^{78}$ MORAES, M. C. B. O direito personalíssimo à filiação e a recusa ao exame de DNA: uma hipótese de colisão de direitos fundamentais. In: LEITE, Eduardo de Oliveira (Coord.).

Grandes Temas da Atualidade - DNA como meio de prova da filiação. Rio de Janeiro: Forense, 2002. p. 226-227.

${ }^{79}$ GAMA, Guilherme Calmon Nogueira da. A nova filiação: o biodireito e as relações parentais: o estabelecimento da parentalidade-filiação e os efeitos jurídicos da reprodução assistida heteróloga. Rio de Janeiro: Renovar, 2003. p. 916.

${ }^{0}$ FAVA. Juliane Carvalho de Souza. A reprodução humana assistida e a tutela jurisdicional da identidade genética. 2009. 98f. Diss. (Mestrado em Direito) - Fac. De Direito, UNIPAR, Umuarama. 2009. p.43. 
No entanto, ao dimensionar o conteúdo do Direito em análise, mesmo relativizando o sigilo em detrimento à identidade e vice-versa, deve o exegeta resguardar a eficácia sistemática, sem desconsiderar o "bem de todos" ${ }^{81}$ no qual a hierarquização deve harmonizar o todo "e não nesta ou naquela parte, em si /considerada", dentro das possibilidades, sem ensejar na quebra de uma garantia fundamental. ${ }^{82}$

De fato, a informação decorrente da identidade pessoal do doador possibilitaria a historicidade pessoal da vida do concebido pelo aspecto biológico, podendo ajudar o indivíduo a compreender seu desenvolvimento físico, esclarecer questionamentos psíquicos atrelados ao inconsciente, pelo seguinte questionamento ilustrativo: "de onde viemos e para onde vamos?" Com amparo no direito à personalidade, quando analisado em sua completude e, com isso, vale dizer, culminando na tutela da própria dignidade da pessoa humana.

Porém, defende-se, salvo melhor juízo, que a carga axiológica do direito fundamental subjetivo ao anonimato do doador de gametas, análogo à privacidade insculpida no artigo $5^{\circ}$, inciso $\mathrm{X}$, da $\mathrm{CF}$, alicerça valores como intimidade e vida privada, além do princípio da solidariedade, "orientador deôntico privilegiado em matéria de relativização de direitos fundamentais", 83 que resguardam o sigilo de identidade pessoal em prol da contemplação da estruturação sócio-afetiva do concebido, com espeque no princípio da afetividade. Logo, o anonimato do doador perfectibilizaria o enfraquecimento do acesso à identidade pessoal do ser oriundo de inseminação artificial na incidência tópico-sistemática.

\section{CONCLUSÃO}

\footnotetext{
${ }^{81} \mathrm{O}$ artigo $3^{\circ}$, inciso IV, da Constituição Federal assim dispõe: "Constituem objetivos fundamentais da República Federativa do Brasil: (...) IV - promover o bem de todos, sem preconceitos de origem, raça, sexo, cor, idade e quaisquer outras formas de descriminação." (grifo nosso) (BRASIL. Constituição (1988). Diário Oficial da União, Brasília, DF, 5 out. 1988. Disponível em: <http://www.planalto.gov.br/ccivil_03/constituicao/constituicaocompilado.htm>. Acesso em: mai. 2015.)

${ }^{82}$ FREITAS, Juarez. A interpretação sistemática do Direito. 5 ed. São Paulo: Malheiros, 2010. p. 180-188.

${ }^{83}$ ARONNE, Ricardo. Ao Egrégio Tribunal Federal. In: R454 Revista Fórum de Direito Civil: RFDC - ano 1, n. 1, (set./dez. 2012). Belo Horizonte, 2012. p. 197.
} 
Observou-se no primeiro capítulo, que o vínculo socioafetivo, embora desnudo de ascendência genética, representa uma condição real que necessita ser analisada minuciosamente pelo exegeta. Aparentemente, a paternidade decorrente da boa-fé, no agir dentro da legalidade, sem intenções secundárias, deve ter amparo no direito de família, de modo que o sigilo da identidade pessoal do doador, nas hipóteses de Reprodução Assistida Heteróloga, torna-se importante nesse processo, para garantir a solidez do grupo familiar, com alicerce no princípio da prioridade absoluta, por analogia ao instituto da doação, nos termos do art. 227 da CF c/c o art. 100, inc. II da Lei 8.0869/90, que estabelece medidas em prol da proteção integral da criança, visando o fortalecimento do vinculo sócio-afetivo, bem como por meio dos encargos familiares, no amparo à psique e afetividade do concebido, oriundos da solidariedade social, objetivo fundamental previsto no art. $3^{\circ}$, inc. I da $\mathrm{CF}$, além do prestígio ao planejamento do grupo familiar sócio-afetivo, resguardando o interesse do filho, com alicerce no bojo axiológico do art. 205 da Constituição Federal.

No segundo capítulo, constatou-se, por outro lado, que o direito ao conhecimento das origens biológicas, enquanto aspecto pertencente à identidade pessoal do indivíduo se relaciona à vedação da privação desarrazoada da família, ao passo que sua constituição deve vir acompanhada de condições mínimas para desenvolvimento de sua personalidade, na promoção de um convívio familiar saudável.

Nessa senda, constatamos que o pleiteio à identidade pessoal no alicerce de aspectos definidores da integridade moral e/ou psíquica (inconsciente) do individuo, oriundo do direito à personalidade, quando analisado em sua completude e, com isso, vale dizer, culminando na tutela da própria dignidade da pessoa humana, possui carga axiológica que impossibilitaria - analisando o caso concreto - o enfraquecimento do direito ao anonimato do doador de gametas, na incidência tópico sistemática, pois o sigilo de identidade alicerça valores atratores como a intimidade e a vida privada, com arrimo no art. $5^{\circ}$, inciso $\mathrm{X}$, da $\mathrm{CF}$, além de um dos pilares do princípio estruturante: a solidariedade, bem como promove o resguardo da contemplação da estruturação sócio-afetiva, com espeque no princípio da afetividade. Assim, o pleiteio à identidade pessoal caracteriza-se por um Poder Fazer a partir de um aparato da modernidade, não possuindo caráter absoluto na ótica ético-jurídica. 


\section{REFERÊNCIAS BIBLIOGRÁFICAS}

AGUIAR, M. Direito à Filiação e Bioética. Rio de Janeiro: Forense, 2005. ALMEIDA, Silmara Juny de Abreu Chinelato e. Reprodução humana assistida: aspectos civis e bioéticos. Tese apresentada ao concurso à Livre-Docência do Departamento de Direito Civil da Faculdade de Direitos da Universidade de São Paulo: Universidade de São Paulo, set. 2000.

ARONNE, Ricardo. Ao Egrégio Supremo Tribunal Federal. In: R454 Revista Forúm de Direito Civil: RFDC - ano 1, n. 1, (set./dez. 2012). Belo Horizonte, 2012.

BRAUNER, Maria Claudia Crespo. Reprodução Humana Assistida e Anonimato de doadores de Gametas: O Direito brasileiro frente às novas formas de paternidade. In: Tereza Rodrigues Vieira (Org.). Ensaios de Bioética e Direito. 2 ed. rev. ampl. atual. Brasíla DF Consulex, 2012.

CABRAL, Hildeliza Lacerda Tinoco Boechat; CAMARDA, Dayane Ferreira. Intimidade versus Origem Genética: A ponderação de interesses aplicada à reprodução Assistida Heteróloga. Disponível em: $<$ wwwantigo.mpmg.mp.br/portal/public/interno/arquivo/id/32427>.

CALLIOLI, Eugenio Carlos. Aspectos da fecundação artificial in vitro. In CAHALI, Yussef Said; CAHALI, Francisco José (Orgs.). Famílias e Sucessões. São Paulo: Revista dos Tribunais, 2011. v. 1.

CASABONA, Carlos Alberto María Romeo. Do Gene ao Direito: sobre implicações jurídicas do conhecimento e intervenção no genoma humano. São Paulo: IDBCRIM, 1999.

CASABONA, Carlos María Romeo. O desenvolvimento do Direito diante das novas Biotecnologias. In: CASABONA, Carlos Alberto María Romeo. SÁ, Maria de Fátima Freire de (Coord). Desafios Jurídicos da Biotecnologia. Belo Horizonte: Mandamentos, 2007.

CÔRREA, Adriana Espíndola. O corpo digitalizado: banco de dados genéticos e sua regulação jurídica. Florianópolis, SC: Conceito Editorial, 2010.

DINIZ, Maria Helena. O Estado do Biodireito. 2. Ed. aum. e atual. de acordo com o novo Código Civil (Lei n. 10.406, de 10-01-2002). São Paulo: Saraiva, 2002.

FAVA. Juliane Carvalho de Souza. A reprodução humana assistida e a tutela jurisdicional da identidade genética. 2009. 98f. Diss. 
(Mestrado em Direito) - Fac. De Direito, UNIPAR, Umuarama. 2009.

FERREIRA, Aline Damasio Damasceno Ferreira. O direito de conhecer a origem genética e o anonimato do doador. Diss. (Mestrado em Direito) - Fac. de Direito, PUCRS, Porto Alegre, 2013.

FREITAS, Juarez. A interpretação sistemática do Direito. São Paulo: Malheiros. 5 ed. 2010.

GAMA, Guilherme Calmon Nogueira da. A nova filiação: o biodireito e as relações parentais: o estabelecimento da parentalidade-filiação e os efeitos jurídicos da reprodução assistida heteróloga. Rio de Janeiro: Renovar, 2003.

LEITE, Eduardo de Oliveira. Procriações artificiais e o direito: aspectos médicos, religiosos, psicológicos, éticos e jurídicos. São Paulo, Ed. Revista dos Tribunais, 1995.

LOBO, Paulo Luiz Netto. Direito ao Estado de filiação e Direito à Origem Genética. Disponível em: $<$ https://www2.cjf.jus.br/ojs2/index.php/revcej/article/viewFile/633 /813>.

MORAES, M. C. B. O direito personalíssimo à filiação e a recusa ao exame de DNA: uma hipótese de colisão de direitos fundamentais. In: LEITE, Eduardo de Oliveira (Coord.). Grandes Temas da Atualidade - DNA como meio de prova da filiação. Rio de Janeiro: Forense, 2002. p. 226-227.

OTERO, Paulo. Personalidade, Identidade Pessoal e Genética do ser humano: um perfil constitucional da bioética. São Paulo: Coimbra Almedina, 1999.

PEREIRA, Renata Braga da Silva. DNA: Análise BioJurídica da Identidade Humana. In BARBOSA, Heloisa Helena, BARRETTO, Vicente de Paulo. Temas de Biodireito e Bioética. Rio de Janeiro: Renovar, 2001.

TARTUCE, Flávio. Novos princípios do Direito de Família brasileiro. Disponível em: <http://www.flaviotartuce.adv.br>.

TEIXEIRA, Ana Carolina Brochado; MOUREIRA, Diogo Luna. A identidade genética e seus reflexos no Direito brasileiro. In: CASABONA, Carlos Maria Romeo, SÁ, Maria de Fátima Freire de. Direito Biomédico: Brasil-Espanha. Belo Horizonte: Ed. PUC Minas, 2011. 

ISSN 1983-4225 - v.9, n.2, dez. 2014. 